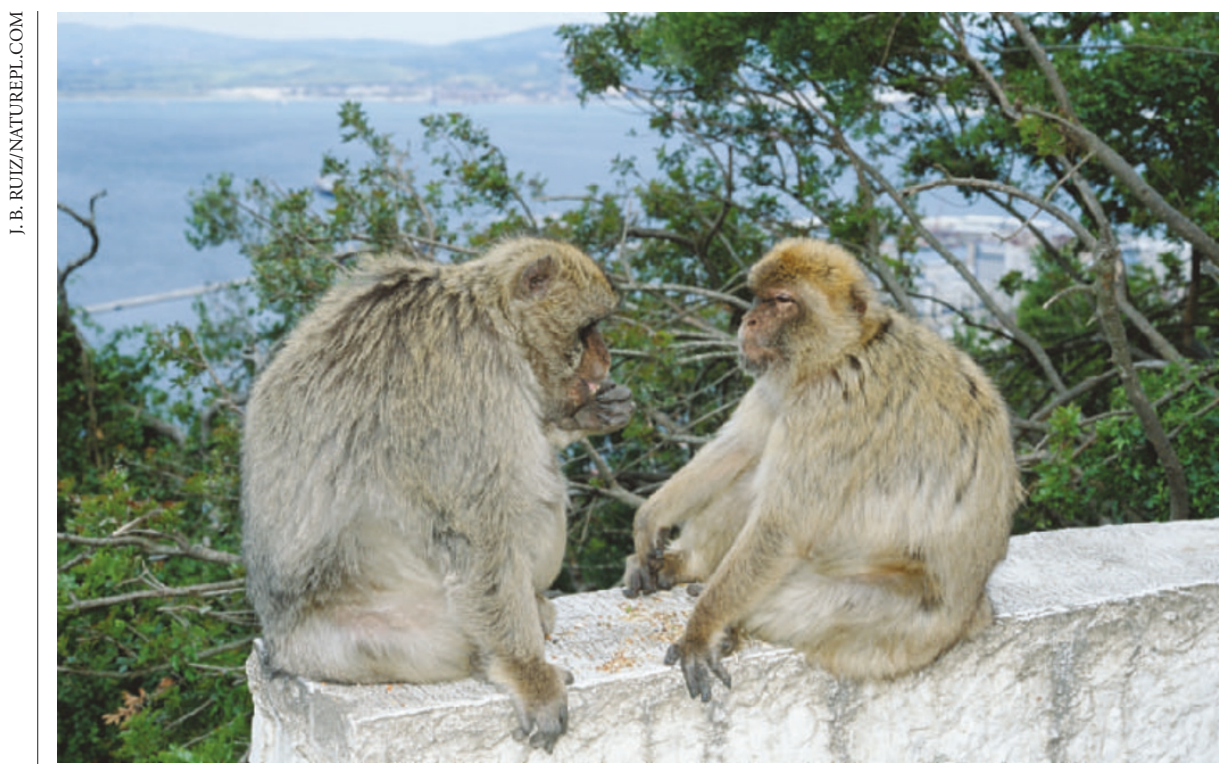

Nuisance neighbours: a number of Gibraltar's macaques have been culled in response to public pressure.

\title{
Primatologist rocks Gibraltar by quitting over macaque cull
}

Quirin Schiermeier, Munich

A top primatologist has pulled out of field research in Gibraltar, in protest at the culling of a group of marauding Barbary macaques that had been part of a long-term conservation study.

Robert Martin, vice-president of the Chicago Field Museum of Natural History, also boycotted an international macaque conference last week in Gibraltar - even though he was one of its organizers.

"The culling without warning of half of our study group has effectively terminated our research project. There is no point in continuing," says Martin.

The couple of hundred semi-wild Barbary macaques (Macaca sylvanus) that populate the rock of Gibraltar, a small British crown colony at the southern tip of Spain, are the only non-human primates living outside captivity in Europe. The well-characterized population provides an ideal model for ecologists studying the genetic effects of habitat fragmentation - a key question in primate ecology and conservation biology.

Eight years ago, Martin, then at the University of Zürich, Switzerland, began monitoring reproduction and genetic variability in a 50-strong macaque colony on Gibraltar's Middle Hill. The study was meant to provide guidelines for the conservation management of threatened wild macaque populations in forest fragments in Algeria and Morocco.

It is not known whether the Barbary macaques are indigenous to Gibraltar, but legend says that when they leave, the peninsula will cease to be British. The myth has been taken so seriously that after a critical decline during the Second World War, Winston Churchill, then Britain's prime minister, issued a 1942 order to import some of the animals from North Africa.

The macaques are a major tourist attraction, but in recent years they have multiplied to nuisance levels. The Gibraltar government has repeatedly ordered the culling of monkeys found roaming built-up areas in search of food. In July, half of Martin's study group were killed after some animals were found vandalizing property and attacking children.

"There was a public-health risk, so we had no choice," says Mark Pizarro, a surgeon at Gibraltar's veterinary clinic.

But Martin says that the monkeys would not have outgrown their habitat if the government had not ignored timely scientific advice. "I submitted as early as 1997 detailed proposals on effective population control by means of contraception, but nothing much was done," he says.

The Gibraltar Ornithological and Natural History Society, which has recently taken over the management of the macaque colony, tried in vain to prevent the culling.

"There was too much public pressure on the government to take action," says John Cortes, general secretary of the society, whose intervention persuaded the government to agree not to have the entire group killed, as had been initially planned.

Martin's withdrawal from the government-sponsored conference is understandable, says Cortes. "But I still believe it would have been better if he had come and made his point here."

www.gib.gi/gonhs/gibraltar/congress.htm
Italy's proposal for technology institute riles researchers

Alison Abbott, Munich

Italy has revealed plans to allocate $€ 1$ billion (US\$1.2 billion) to set up what the government hopes will become a world-class institute of technology.

But many Italian researchers are suspicious of the surprise proposal, which bypasses existing research institutes and agencies. They also complain that a detailed concept for the facility, named the Italian Institute of Technology (IIT), has yet to be set out.

Cash for the institute was included last month in Italy's budget for 2004, which is likely to be approved by the parliament in Rome later this month.

But the initial plans were first outlined by Vittorio Grilli, the Italian government's chief accountant, at a seminar at Harvard University on 23 October. Grilli, one of the architects of the scheme, told the seminar that Italy needs to improve its track record in research and technology transfer.

The IIT will be funded by an endowment over ten years, with the first $€ 100$ million due in January. Italian scientists, however, are less than thrilled that the government plans to lavish funds on a new project while existing institutions are starved of resources.

Italian research has been in crisis for years, as successive governments have tried to implement reforms and cut red tape. Most research organizations are now in the hands of commissioners appointed by the government to oversee such reforms.

Two of the commissioners - Adriano De Maio from the CNR, the national research council, and Carlo Rubbia from ENEA, the energy and environment agency - have spoken out against the IIT concept, arguing that the sort of money set aside for it could have been used to give the reforms a chance to work.

"It's a bit schizophrenic of the government to install commissioners to make research more efficient, then put significant new funds elsewhere," notes physicist Roberto Battiston of the University of Perugia.

Emilio Bizzi, an Italian neuroscientist at the Massachusetts Institute of Technology who has advised successive Italian governments, says he sympathizes with the scientists' concerns. But he adds that he understands the government's frustration with existing institutions. "I'm not surprised the government wanted to bypass the system," he says. "But whether it was wise to do so, I can't say." Government officials declined to comment. 